\title{
Determination of Radon and Thoron Concentrations in Different Parts of Some Plants Used in Traditional Medicine Using Nuclear Track Detectors
}

\author{
L. Oufni ${ }^{1, *}$, N. Manaut ${ }^{3}$, S. Taj ${ }^{2}$, B. Manaut ${ }^{2}$ \\ ${ }^{1}$ Department of Physics (L.P.M.M.), Faculty of Sciences and Techniques, University Sultan Moulay Slimane, Beni-Mellal, Morocco \\ 2Department of Biology, Ecology and Environment Laboratory, Faculty of Science Semlalia, University Cadi Ayyad, Morocco \\ ${ }^{3}$ Polydisciplinary Faculty (L.I.R.S.T.), University Sultan Moulay Slimane, Beni-Mellal, Morocco \\ *Corresponding author: oufni@yahoo.com
}

Received December 09, 2012; Revised April 29, 2013; Accepted April 30, 2013

\begin{abstract}
The paper presents results of radon $\left({ }^{222} \mathrm{Rn}\right)$ and thoron $\left({ }^{220} \mathrm{Rn}\right)$ levels in different parts of some selected plants used in Moroccan cooking and traditional medicine. Plant uptake of radionuclide is one of many vectors for introduction of contaminants into the human food chain. Thus, it is critical to understand the soil-plant relationships that control nuclide bioavailability. The radon and thoron concentrations have been determined in the studied samples and their corresponding soils, and that using the technique based on two types of solid state nuclear track detectors (SSNTDs) LR-115 type-II and CR-39. Transfer factors (TF) of ${ }^{222} \mathrm{Rn}$ and ${ }^{220} \mathrm{Rn}$ from soil to parts of various studied plants have been determined. TF for roots were higher than those for stems and leaves. The radon and thoron activities in the soils have been found varying from $0.87 \pm 0.06 \mathrm{~Bq} \cdot \mathrm{kg}^{-1}$ to $6.20 \pm 0.47 \mathrm{~Bq} \cdot \mathrm{kg}^{-1}$ and from 30 $\pm 2.30 \mathrm{mBq} \cdot \mathrm{kg}^{-1}$ to $195 \pm 16 \mathrm{mBq} \cdot \mathrm{kg}^{-1}$, respectively. These values are lower in the leaves and stems than those determined in the roots of the studied plants. The aim of this study was to analyze the radon transfer from soil to different compartments of these plants and then to evaluate the radiotoxicity caused by radon in order to contribute to the health risk assessment.
\end{abstract}

Keywords: radon, thoron, dos of a-particles, nuclear track detectors, soil, plant

\section{Introduction}

Radon ${ }^{222} \mathrm{Rn}$; originating from ${ }^{238} \mathrm{U}$ with a half-life of 3.82 days, Figure 1) and thoron $\left({ }^{220} \mathrm{Rn}\right.$; originating from ${ }^{232} \mathrm{Th}$ with half-life of $55.3 \mathrm{sec}$, Figure 2) are natural radioactive elements that are everywhere presents in the earth crust, and from they are gases, they have great mobility to get to considerable distances in geological media. This property makes both useful as trace elements in the environment. Their concentrations in the geological formations depend on diffusion and convection of the gas and on its decay rate [1]. Radon and thoron generally migrate together to the surface along faults and fractures that are produced in rocks in the Earth's crust within geological times. Due to the much shorter half-life of thoron in contrast with the longer half-life of radon, thoron researches may be more accurate to establish the location of the tectonic elements in the earth crust. This statement can be verified by monitoring the flux of radon and thoron to the surface, or measuring its concentration in soil gas respectively [2].

Due to its long half-life time, radon $\left(T_{1 / 2}=3.82 \mathrm{~d}\right)$ is considered the most significant isotope of radon problem in the environmental studies. It is well known that the radiations emitted from the primordial radionuclide originating from the Earth's crust are the major contributors to the total background exposures to the human populations. They include external gamma exposures and inhalation exposures, approximately in equal measure; the latter is due to radon, thoron and their progeny in the indoor environment. Radon, a progeny of uranium-238 $\left.{ }^{238} \mathrm{U}\right)$, is a colorless, odorless, noble and radioactive gas. Its half-life is 3.82 days and its decay with the emission of $5.48 \mathrm{MeV} \alpha$-particles. Radon and its shortlived decay products in dwellings present the main source of public exposure from the natural contributing to nearly $50 \%$ of the global effective dose to population [3]. Lung cancer pathologies caused by inhalation exposure to radon is due to alpha-dose deposited by short-lived radon decay products. It is well known that exposure of population to high concentrations of radon and its daughters for a long period leads to some pathological effects like the respiratory functional changes and the high occurrence of lung cancer [4]. Radon appears mainly by diffusion processes from the point origin following $\alpha$-decay of ${ }^{226} \mathrm{Ra}$ in underground soil. Radon (and thoron) diffusion and transport through different media is a complex process and is affected by several factors [5,6]. It is well known that for material medium, the porosity, permeability and the diffusion coefficient are the parameters which can affect directly the capacity to hinder the flow of radon soil gas.

To estimate a realistic radiation exposure of the population, the behavior of the deposited radionuclides in the food chain has to be known. After the Chernobyl 
accident, research activities have been focused on the soilplant transfer of Cesium isotopes and the long livedfission products. Much less is known about the transfer of the nuclides of the primordial decay chains, most investigations refer to ${ }^{226} \mathrm{Ra}$ [7]. People from all cultures have traditionally relied on natural resources, mainly of plant origin, as folk medicines to treat diseases and disorders. Herbs have also been the source of many "modern" single-component drugs. Today, medicinal plants are being accepted and used increasingly by general populations in both Eastern and Western countries as medicines or dietary supplements, either alone or in combination with more modern chemotherapeutic agents [8]. In the present study, we used a method based on calculating the critical angles of the LR-115 type II and CR-39 SSNTDs for alpha-particles emitted by the uranium (radon) and thorium (thoron) series and exploiting the corresponding track densities for evaluating the resulting alpha-activity in the studied soils and the inside corresponding plants which are used as traditional medicine in the North of Africa. We also determine annual effective dose rate due to radon and thoron inside the different parts of the studied medicinal plant samples. These measurements of radon and thoron activities were used to determine their soil-to-plant transfer factors (TF). The SSNTD technique has also been used for determining alpha and beta dose-rates, the radon diffusion coefficient and radon exhalation rate in various quaternary samples $[5,9]$. This technique has been previously used to study the indoor radon level in different dwellings [10,11,12,13], and has been used to study the transfer of uranium and thorium from soil to different parts of medicinal plant [14].

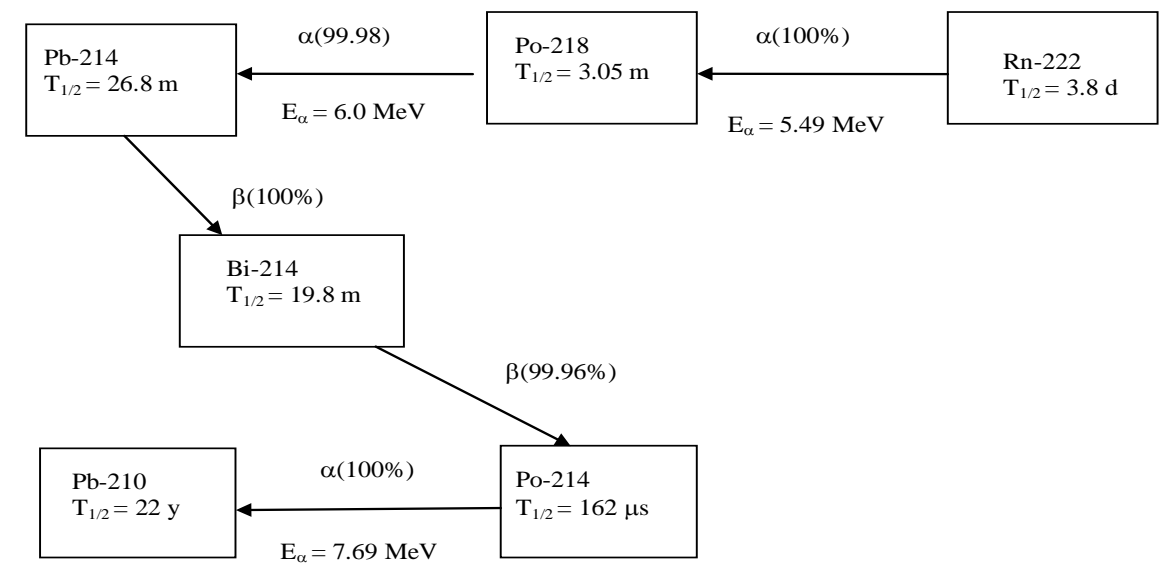

Figure 1. Radon decay products

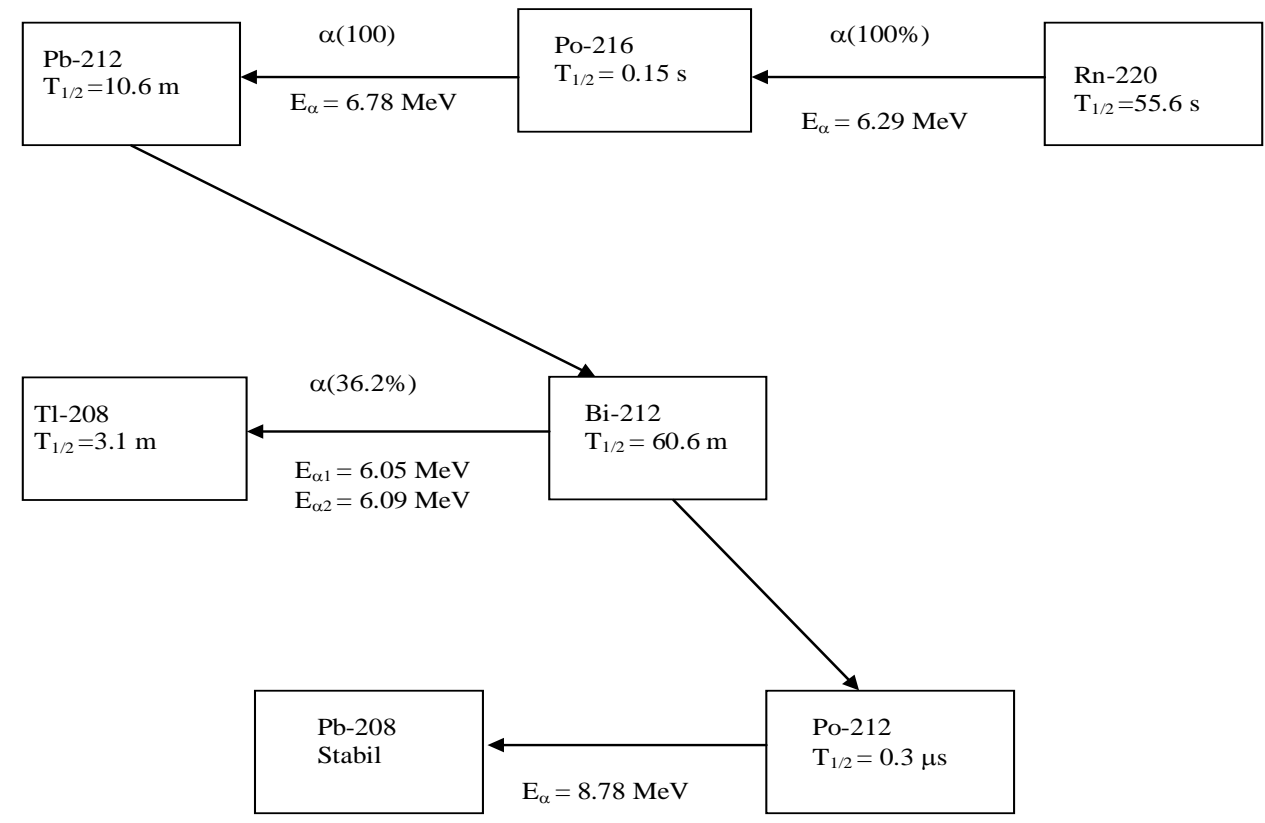

Figure 2. Thoron decay products

\section{Materials and Methods}

\subsection{Geological Setting and Samples}

Soil and medicinal plant samples were collected from different fields throughout Beni-Mellal area (Middle of
Morocco, Figure 3) during the spring and summer period of 2011. The Beni-Mellal area has a Mediterranean climate with continental influences and situated between $32^{\circ} 20^{\prime} 20.61$ ” North latitude and 6²1'47.41” Western longitude with elevation of $514 \mathrm{~m}$. The mean annual precipitation is $520 \mathrm{~mm}$, and the mean annual temperature $12^{\circ} \mathrm{C}$. The soil samples collected from each place were 
dried at $70^{\circ} \mathrm{C}$ for $48 \mathrm{~h}$ until they reach a constant mass, the ground to pass through $2 \mathrm{~mm}$ sieve and then were thoroughly mixed and pulverized with an agate ball mill. The soil of the experimental areas had 34.2\% clay, 20\% loam and 38\% sand. Above-ground plant material was weighed, dried at $100^{\circ} \mathrm{C}$ until constant weight and milled before the radioactivity quantification.

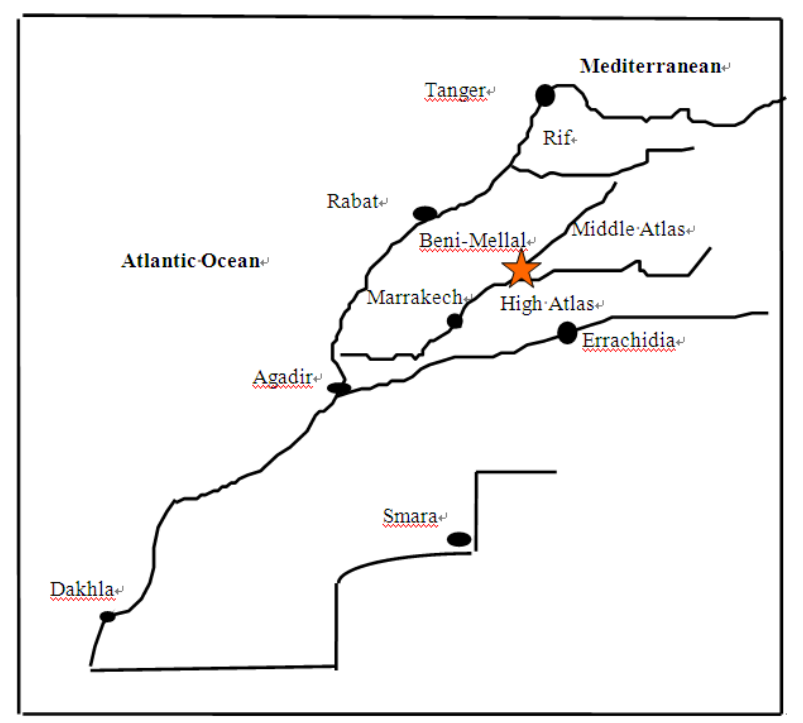

Figure 3. Map showing the localization of the studied samples in the Beni-Mellal region (Morocco)

\subsection{Method of Study}

According to a method developed by [15] when the CR-39 and LR-115 type II SSNTD are separately placed in close contact with a homogeneous studied sample (soils and the studied plants) in a hermetically sealed cylindrical plastic container for 1 month (Figure 4), one can evaluate radon (Ac $\left.\left({ }^{222} \mathrm{Rn}\right)\right)$ and thoron (Ac $\left.\left({ }^{220} \mathrm{Rn}\right)\right)$ alpha-activities inside the sample by using the following equations:

$$
D_{G}(L R)=\frac{d_{s}}{4} \cos ^{2} \theta_{c} A_{c}\left({ }^{222} R n\right) \Delta R_{s}\left[8+6 \frac{A_{c}\left({ }^{220} R n\right)}{A_{c}\left({ }^{222} R n\right)}\right]
$$

and

$$
D_{G}(C R)=\frac{d_{s}}{4} \cos ^{2} \theta_{c} A_{c}\left({ }^{222} R n\right) \Delta R_{s}\left[\sum_{i=1}^{8} k_{i} R_{i \alpha}+\frac{A_{c}\left({ }^{220} R n\right)}{A_{c}\left({ }^{222} R n\right)} \sum_{i=1}^{7} k_{i} R_{i \alpha}\right]
$$

where $D_{G}(L R)$ and $D_{G}(C R)$ are the track density rates (tracks $\mathrm{cm}^{-2} \mathrm{~s}^{-1}$ ) registered on the LR-115 type II and CR39, $A_{c}\left({ }^{222} \mathrm{Rn}\right)$ and $A_{c}\left({ }^{220} \mathrm{Rn}\right)$ are the radon $\left({ }^{222} \mathrm{Rn}\right)$ and thoron $\left({ }^{220} \mathrm{Rn}\right) \alpha$-activities $\left(\mathrm{Bq} \cdot \mathrm{g}^{-1}\right)$ inside the studied material sample, $\mathrm{k}_{\mathrm{i}}$ is the branching ratio corresponding to the disintegration of the nuclei of uranium and thorium groups, $R_{i \alpha}$ is the range of $\alpha$-particle of energy $E_{\alpha i}$ in the material sample and it is calculated by means of the TRIM programme [16], $d_{s}$ is the sample density, $\theta_{C}^{\prime}$ and $\theta_{C}$ are the critical angles of etching for the LR-115 type-II and CR-39 are respectively given by:

$$
\cos \theta_{c}=\frac{1}{1+\exp \left(-0.27 R_{D}+3\right)}
$$

and

$$
\cos \theta_{c}=\frac{1}{11.6 R_{D}^{-0.464}}
$$

where $R_{D}^{\prime}, R_{D}$ are the ranges of $\alpha$-particles in LR-115-II and CR-39 SSNTD in $\mu \mathrm{m} . \Delta \mathrm{R}_{\mathrm{S}}=\mathrm{R}_{\max }\left(\mathrm{E}_{\max }\right)-\mathrm{R}_{\min }\left(\mathrm{E}_{\min }\right)$, $R_{\max }$ and $R_{\min }$ are the ranges of $\alpha$-particles in the sample which corresponds to the energy windows $E_{\max }$ and $E_{\min }$ at the upper and lower ends, both of which are functions of the detector and critical angle.

Combining Equations. (1) and (2), we obtain the following relationship between radon-to-thoron ratios and track densities:

$$
\frac{\left.A_{C}{ }^{222} R n\right)}{\left.A_{C}{ }^{220} R n\right)}=\frac{\gamma \sum_{i=1}^{7} k_{i} R_{i \alpha}-6 \beta \Delta R_{s}}{8 \beta \Delta R_{S}-\gamma \sum_{i=1}^{8} k_{i} R_{i \alpha}}
$$

where: $\gamma=\frac{\cos ^{2} \theta_{c}}{\cos ^{2} \theta_{c}^{\prime}}$ and $\beta=\frac{D_{G}(C R)}{D_{G}(L R)}$

From where one obtains the Radon activity given by:

$$
A_{c}\left({ }^{222} R n\right)=\frac{2 D_{G}(L R)}{\Delta R_{s} d_{s} \cos ^{2} \theta_{c}^{\prime}\left[4+3 \frac{A_{c}\left({ }^{220} R n\right)}{A_{c}\left({ }^{222} R n\right)}\right]}
$$

And therefore, we determine the thoron activity.

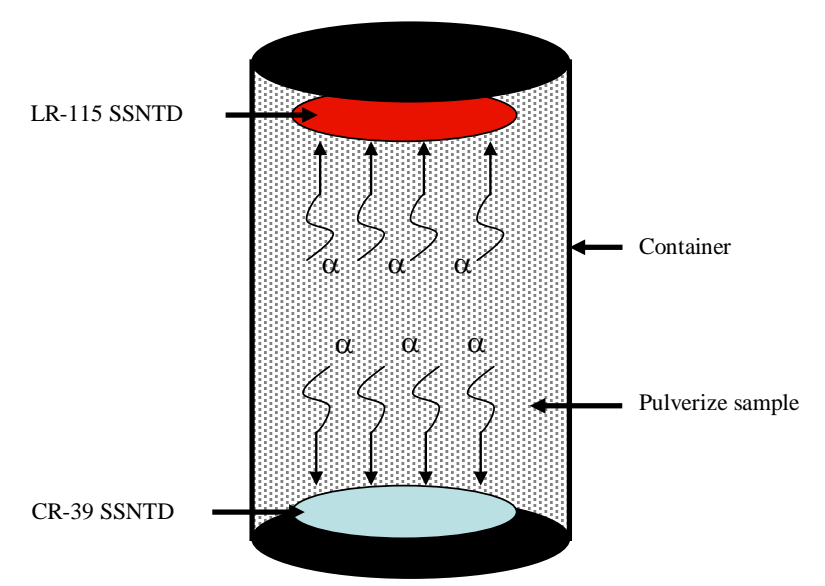

Figure 4. Arrangement of the solid state nuclear track detectors on a studied sample in a cylindrical plastic container

\subsection{Calculation of the Transfer Factor}

Plants are the primary recipients of radioactive contamination to the food chain following atmospheric releases of radionuclide. Vegetation may be the subject to direct or indirect contamination [17]. Absorption of radionuclide from soils into plants is usually quantified in terms of the transfer (or concentration) factor, which is defined as the ratio of the radioactivity per unit dry weight of plant to the radioactivity per dry weight of soil in the rooting zone [18]. Transfer factor (TF) is defined as the ratio of radionuclide concentrations in vegetation and soil.

The soil to plant transfer factors was determined according to the relation.

$$
\mathrm{TF}=\frac{\text { Activity concentration of plant }(\mathrm{Bq} / \mathrm{kg} \text { dry weight })}{\text { Activity concentration of soil }(\mathrm{Bq} / \mathrm{kg} \text { dry weight })}
$$

The dry weight was preferred because the amount of radioactivity per kilogram dry weight is much less 
variable than the amount per unit fresh weight. It reduces uncertainties [19].

\subsection{Dose Calculation Method}

Effective dose is a useful concept that enables the radiation doses from different radionuclides and from different types and sources of radioactivity to be added. It is based on the risks of radiation induced health effects and the use of the International Commission on Radiological Protection (ICRP) metabolic model that provides relevant conversion factors to calculate effective doses from the total activity concentrations of radionuclides measured in foods [20,21]. Estimates of the radiation induced health effects associated with intake of radionuclides in the body are proportional to the total dose delivered by the radionuclides while resident in the various organs.

Based on reference [9], we determine the effective dose rate (noted $D_{\alpha}$, in $m S v \cdot y^{-1}$ ) due to radon and thoron inside the studied medicinal plants. Otherwise, the $D_{\alpha}$ gave the committed effective radiation (of radon and thoron) dose due to ingestion of terrestrial studied plant. It's given by:

$$
\mathrm{D}_{\alpha}=\text { DCF.A }_{\mathrm{c}}\left({ }^{222} \mathrm{Rn}\right)\left[\sum_{\mathrm{i}=1}^{8} \mathrm{R}_{\mathrm{i} \alpha}+\frac{\mathrm{A}_{\mathrm{c}}\left({ }^{220} \mathrm{Rn}\right)}{\mathrm{A}_{\mathrm{c}}\left({ }^{222} \mathrm{Rn}\right)} \sum_{\mathrm{i}=1}^{7} \mathrm{k}_{\mathrm{i}} \mathrm{R}_{\mathrm{i} \alpha}\right]
$$

where DCF is the dose conversion factor (the factor to convert Bq. $\mathrm{g}^{-1} \cdot \mathrm{MeV}$ to mRad. $\mathrm{y}^{-1}$ ).

\section{Results and Discussion}

\subsection{Distribution of Radon and Thoron in the Studied Samples}

Concentrations of radon and thoron have been determined inside various natural material samples (soils and the corresponding medicinal plants). Data obtained are shown in Table 1, Table 2 and Table 3. From the statistical error on track counting one can determine the error on track density rate and then evaluate the relative uncertainty of the radon and thoron determination that is of $8 \%$.

From the Table 1 we found that the radon and thoron concentrations in soil samples varies from a minimum of $65.4 \pm 5.7$ and $26.8 \pm 2.4 \mathrm{~Bq} \mathrm{~kg}^{-1}$ to a maximum of $96.1 \pm$ 8.6 and $41.8 \pm 3.8 \mathrm{~Bq} \mathrm{~kg} \mathrm{~kg}^{-1}$, respectively. We notice that alpha-activities due to radon and thoron are clearly different in the studied soil samples collected from various places. This difference can be explained by the transport conditions and of the uranium and thorium dissolution at the time of the sedimentation of these soils (because ${ }^{222} \mathrm{Rn}$ and ${ }^{220} \mathrm{Rn}$ are members of the ${ }^{238} \mathrm{U}$ and ${ }^{232} \mathrm{Th}$ decay series, respectively).

Radon and thoron activities have been determined inside parts of various medicinal plants (Table 2 and Table 3) widely used in Moroccan traditional medicine. These activities are different from one plant to another. It is to be noticed that roots of each studied plant show higher radon and thoron concentration than the other parts (stems, leaves fruits and seeds) of the plant materials: i.e. that the distribution of radon and thoron in different parts of the studied plants showed the decreasing trend as root $>$ leaf $>$ stem $>$ fruit (or seed). In this case, one can write:
$\left[A_{C}\left({ }^{222} R n,{ }^{220} R n\right)\right.$ root $]>\left[A_{C}\left({ }^{222} R n,{ }^{220} R n\right)\right.$ stem $]>\left[A_{C}\left({ }^{222} R n,{ }^{220} R n\right)\right.$ leaf $]$

Table 1. Data obtained for the radon and thoron alpha-activities in soil samples corresponding to the different studied plants.

\begin{tabular}{|c|c|c|c|c|c|}
\hline \multirow[t]{2}{*}{$\begin{array}{l}\text { Medicinal } \\
\text { plants }\end{array}$} & \multirow[t]{2}{*}{$\begin{array}{l}\text { Samples } \\
\text { number }\end{array}$} & \multicolumn{2}{|c|}{$\begin{array}{c}\text { Track densities } \\
\left(\text { Track.cm }{ }^{-2} \cdot \mathrm{d}^{-1}\right) \times 10^{-4}\end{array}$} & \multicolumn{2}{|c|}{$\begin{array}{l}\text { Mean activity } \\
\left(\mathrm{Bq} \cdot \mathrm{kg}^{-1}\right)\end{array}$} \\
\hline & & $\mathrm{D}_{\mathrm{G}}(\mathrm{CR})$ & $\mathrm{D}_{\mathrm{G}}(\mathrm{LR})$ & $\mathrm{A}_{c}\left({ }^{222} \mathrm{Rn}\right)$ & $\mathrm{A}_{c}\left({ }^{220} \mathrm{Rn}\right)$ \\
\hline $\begin{array}{c}\text { Thymus } \\
\text { vulgaris L. }\end{array}$ & 6 & $22.86 \pm 1.92$ & $5.04 \pm 0.42$ & $96.1 \pm 8.6$ & $41.8 \pm 3.8$ \\
\hline $\begin{array}{l}\text { Coriandrum } \\
\text { sativum L. }\end{array}$ & 8 & $18.52 \pm 1.45$ & $4.11 \pm 0.33$ & $77.5 \pm 7.1$ & $34.3 \pm 3.1$ \\
\hline $\begin{array}{l}\text { Citrus } \\
\text { colocynthis } \\
\text { (L.) Schrad }\end{array}$ & 4 & $21.05 \pm 1.72$ & $4.67 \pm 0.36$ & $88.6 \pm 7.8$ & $38.7 \pm 3.4$ \\
\hline $\begin{array}{c}\text { Chenopodium } \\
\text { ambrosioides } \\
\text { L. }\end{array}$ & 6 & $15.56 \pm 1.30$ & $3.45 \pm 0.28$ & $65.4 \pm 5.7$ & $26.8 \pm 2.4$ \\
\hline $\begin{array}{c}\text { Retama } \\
\text { sphaerocarpa } \\
\text { (L.) }\end{array}$ & 4 & $19.12 \pm 1.44$ & $4.24 \pm 0.34$ & $80.1 \pm 7.3$ & $34.6 \pm 3.1$ \\
\hline $\begin{array}{l}\text { Petroselinum } \\
\text { crispum Mill. }\end{array}$ & 7 & $22.35 \pm 1.74$ & $4.96 \pm 0.40$ & $93.4 \pm 8.4$ & $39.2 \pm 3.5$ \\
\hline $\begin{array}{l}\text { Ziziphus lotus } \\
\text { (L.) Lam. }\end{array}$ & 4 & $19.62 \pm 1.62$ & $4.36 \pm 0.34$ & $82.5 \pm 7.5$ & $35.8 \pm 3.2$ \\
\hline $\begin{array}{l}\text { Mentha } \\
\text { spicata L. }\end{array}$ & 5 & $18.15 \pm 1.50$ & $4.03 \pm 0.33$ & $76.3 \pm 6.8$ & $34.2 \pm 3.1$ \\
\hline $\begin{array}{c}\text { Artemisia } \\
\text { herba-alba } \\
\text { Asso. }\end{array}$ & 8 & $17.03 \pm 1.35$ & $3.77 \pm 0.31$ & $71.1 \pm 6.4$ & $27.6 \pm 2.4$ \\
\hline $\begin{array}{l}\text { Rosmarinus } \\
\text { officinalis L. }\end{array}$ & 7 & $19.94 \pm 1.65$ & $4.43 \pm 0.37$ & $83.5 \pm 7.5$ & $38.4 \pm 3.4$ \\
\hline $\begin{array}{l}\text { Peganum } \\
\text { harmala L. }\end{array}$ & 6 & $17.83 \pm 1.42$ & $3.97 \pm 0.31$ & $75.4 \pm 6.7$ & $30.6 \pm 2.7$ \\
\hline $\begin{array}{l}\text { Marrubium } \\
\text { vulgare L. }\end{array}$ & 5 & $22.36 \pm 1.87$ & $4.95 \pm 0.40$ & $93.5 \pm 8.4$ & $40.2 \pm 3.6$ \\
\hline $\begin{array}{c}\text { Artemisia } \\
\text { absinthium L. }\end{array}$ & 5 & $17.35 \pm 1.46$ & $3.84 \pm 0.32$ & $72.6 \pm 6.5$ & $28.3 \pm 2.5$ \\
\hline
\end{tabular}

From the Table 2, we found that the radon activity in the parts of studied medicinal plants varies from a minimum of $0.87 \pm 0.0 .06 \mathrm{~Bq} \cdot \mathrm{kg}^{-1}$ (in the seed of Coriandrum sativum L.) to a maximum of $6.20 \pm$ $0.47 \mathrm{~Bq} . \mathrm{kg}^{-1}$ (in the root of Marrubium vulgare L.). While we note that the thoron concentration in most of the studied plants is very low compared to that of radon. From the Table 3, we found that the thoron concentration in the parts of studied medicinal plants varies from a minimum of $30 \pm 2.30 \mathrm{mBq} \cdot \mathrm{kg}^{-1}$ (in the seed of Coriandrum sativum L.) to a maximum of $195 \pm 16 \mathrm{mBq} \cdot \mathrm{kg}^{-1}$ (in the root of Marrubium vulgare L.). These results show that radon and thoron can be transferred from soil into plants via the root absorption. The concept of the ${ }^{222} \mathrm{Rn}$ (and ${ }^{220} \mathrm{Rn}$ ) soilpathway is shown in Figure 5 with its three parts: the soil solids (minerals, particulate organic matter), the soil solution and the plant. The exchange between the soil solids and the soil solution is the chemical reaction. The uptake of these radionuclides from the soil solution is controlled by plant physiology. Thus, it is known that radionuclides occur naturally in soil incorporated metabolically into plants. In addition to root uptake, direct 
deposition may occur on foliar surfaces, and when this happens the radionuclides may be absorbed metabolically by the plants. Uptake of the radon and thoron by plants depends to a considerable degree on whether it remains within reach of the roots of plants and the extent to which it is chemically available. The rates at which the various radionuclides will migrate through different soils under varying conditions of $\mathrm{pH}$ and moisture are not well known.

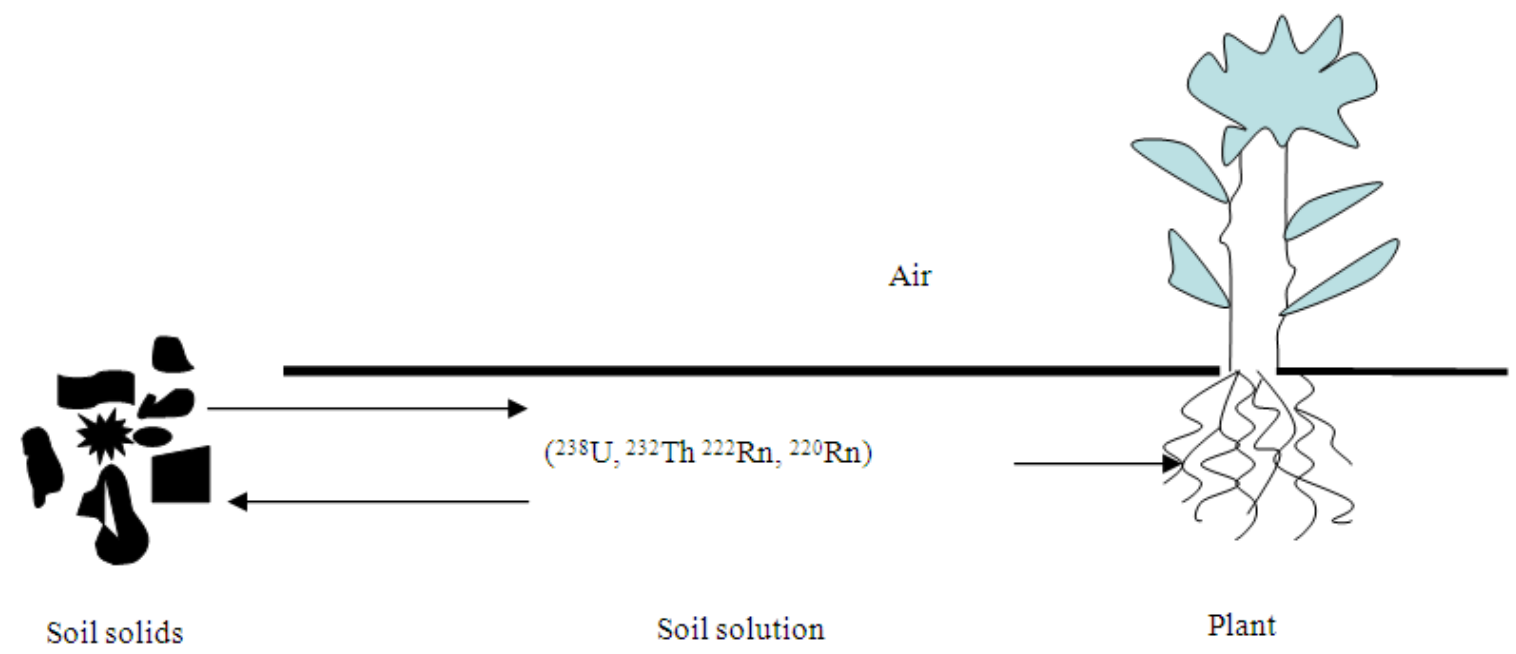

Figure 5. A conceptual presentation of the soil-plant transfer of radionuclide

Table 2. Activity of ${ }^{222} \mathrm{Rn}\left(\mathrm{Bq} \mathrm{kg}^{-1}\right.$, dry weight) inside different parts of the studied medicinal plants

\begin{tabular}{|c|c|c|c|c|c|}
\hline \multirow[t]{2}{*}{ Medicinal plants } & \multicolumn{5}{|c|}{ Activity of ${ }^{222} \mathrm{Rn}\left(\mathrm{Bq} \mathrm{kg}{ }^{-1}\right.$, dry weight) } \\
\hline & Root & Stem & Leaf & Fruit & Seed \\
\hline Thymus vulgaris L. & $5.93 \pm 0.41$ & $3.23 \pm 0.25$ & $1.76 \pm 0.14$ & ------ & ------ \\
\hline Coriandrum sativum L. & $5.06 \pm 0.40$ & $2.65 \pm 0.20$ & $1.50 \pm 0.12$ & ------ & $0.87 \pm 0.06$ \\
\hline Citrus colocynthis (L.) Schrad & $5.68 \pm 0.45$ & $3.15 \pm 0.24$ & $1.88 \pm 0.15$ & $1.08 \pm 0.07$ & ------ \\
\hline Chenopodium ambrosioides L. & $4.26 \pm 0.33$ & $2.24 \pm 0.18$ & $1.46 \pm 0.12$ & ------ & ------ \\
\hline Retama sphaerocarpa L. & $5.30 \pm 0.42$ & $2.93 \pm 0.23$ & $1.88 \pm 0.15$ & ------ & ------ \\
\hline Petroselinum crispum Mill. & $6.18 \pm 0.50$ & $3.10 \pm 0.25$ & $1.87 \pm 0.15$ & ------ & $1.21 \pm 0.9$ \\
\hline Ziziphus lotus (L.) Lam. & $5.23 \pm 0.41$ & $2.93 \pm 0.23$ & $1.62 \pm 0.12$ & $1.16 \pm 0.09$ & ------ \\
\hline Mentha spicata L. & $4.82 \pm 0.40$ & $2.45 \pm 0.20$ & $1.43 \pm 0.11$ & ------ & ------ \\
\hline Artemisia herba-alba Asso. & $4.63 \pm 0.36$ & $2.70 \pm 0.22$ & $1.74 \pm 0.13$ & ----- & ------ \\
\hline Rosmarinus officinalis L. & $5.53 \pm 0.43$ & $3.05 \pm 0.24$ & $2.10 \pm 0.17$ & ----- & ----- \\
\hline Peganum harmala L. & $4.70 \pm 0.37$ & $2.56 \pm 0.20$ & $1.78 \pm 0.14$ & ----- & $1.06 \pm 0.07$ \\
\hline Marrubium vulgare L. & $6.20 \pm 0.47$ & $3.34 \pm 0.26$ & $1.94 \pm 0.15$ & ------ & ------ \\
\hline Artemisia absinthium L. & $4.73 \pm 0.37$ & $2.62 \pm 0.20$ & $1.75 \pm 0.14$ & ------ & ------ \\
\hline
\end{tabular}

Table 3. Activity of ${ }^{220} \mathrm{Rn}\left(\mathrm{mBq} \mathrm{kg}{ }^{-1}\right.$, dry weight) inside different parts of the studied medicinal plants

\begin{tabular}{|c|c|c|c|c|c|}
\hline \multirow[t]{2}{*}{ Medicinal plants } & \multicolumn{5}{|c|}{ Activity of ${ }^{220} \mathrm{Rn}$ (mBq kg-1 , dry weight) } \\
\hline & Root & Stem & Leaf & Fruit & Seed \\
\hline Thymus vulgaris L. & $189 \pm 15$ & $103 \pm 8.0$ & $53 \pm 4.3$ & ----- & ----- \\
\hline Coriandrum sativum L. & $144 \pm 11$ & $93 \pm 7.5$ & $45 \pm 3.5$ & ----- & $30 \pm 2.30$ \\
\hline Citrus colocynthis (L.) Schrad & $169 \pm 13$ & $111 \pm 9.0$ & $52 \pm 4.1$ & $41 \pm 3.30$ & ------ \\
\hline Chenopodium ambrosioides L. & $114 \pm 9$ & $72 \pm 5.8$ & $34 \pm 2.7$ & ------ & ------ \\
\hline Retama sphaerocarpa L. & $157 \pm 13$ & $95 \pm 7.7$ & $48 \pm 3.8$ & ----- & ------ \\
\hline Petroselinum crispum Mill. & $184 \pm 15$ & $112 \pm 9.0$ & $50 \pm 4.1$ & ------ & $40 \pm 3.24$ \\
\hline Ziziphus lotus (L.) Lam. & $166 \pm 13$ & $81 \pm 6.7$ & $44 \pm 3.5$ & $33 \pm 2.62$ & ----- \\
\hline Mentha spicata L. & $163 \pm 13$ & $68 \pm 5.4$ & $47 \pm 3.7$ & ------ & ----- \\
\hline Artemisia herba-alba Asso. & $130 \pm 10$ & $62 \pm 5.0$ & $38 \pm 3.1$ & ------ & ------ \\
\hline Rosmarinus officinalis L. & $187 \pm 15$ & $110 \pm 99.0$ & $52 \pm 4.2$ & ------ & ------ \\
\hline Peganum harmala L. & $140 \pm 11$ & $83 \pm 6.5$ & $39 \pm 3.1$ & ------ & $32 \pm 2.64$ \\
\hline Marrubium vulgare L. & $195 \pm 16$ & $106 \pm 8.5$ & $55 \pm 4.5$ & ------ & ------ \\
\hline Artemisia absinthium L. & $135 \pm 11$ & $67 \pm 5.4$ & $38 \pm 3.1$ & ------ & ------ \\
\hline
\end{tabular}

\subsection{Transfer Factor}

The radon and thoron activities in the studied soils and inside parts of medicinal plants can be used for the determination of soil-to-plant transfer factor (transfer coefficients between soil and plants). In the literature this transfer factor (TF) is also known as the relative concentration factor [22], or plant-soil concentration ratio [23].

The TF values for ${ }^{222} \mathrm{Rn}$ and ${ }^{220} \mathrm{Rn}$ to different parts (roots, stems, leaves, fruits and seeds) of various plants used in traditional folk medicine are shown in Table 4 
Table5. The calculated ${ }^{222} \mathrm{Rn} \mathrm{TF}$ values for all plant species were in the order of $10^{-2}$ varying from $1.12 \times 10^{-2}$ to $6.63 \times 10^{-2}$. While, the calculated ${ }^{220} \mathrm{Rn}$ TF values for all studied plants were in the order of $10^{-3}$ varying from $0.87 \times 10^{-3}$ to $4.85 \times 10^{-3}$. Differences between ${ }^{222} \mathrm{Rn}$ and ${ }^{220} \mathrm{Rn}$ TF values for various plant species are due to different characteristics of the plants. ${ }^{222} \mathrm{Rn}$ and ${ }^{220} \mathrm{Rn}$ TF values from soil to roots of vegetables were found to be higher than stems, leaves and fruits (or seeds). The reason for the high variability of soil-to-plant transfer factors is obvious. This macroscopic parameter integrates a number of soil chemical, soil biological, hydrological, physical and plant physiological processes. The comparison with investigations reviewed given by IAEA demonstrated the wide variation of obtained transfer factors, depending on environmental conditions and selected plant species [19].

Table 4. TF values of radon ( $\left.{ }^{222} \mathrm{Rn}\right)$ to different parts of the studied medicinal plants

\begin{tabular}{|c|c|c|c|c|c|}
\hline \multirow[t]{2}{*}{ Medicinal plants } & \multicolumn{5}{|c|}{ Transfer Factor (TF) $\times 10^{-2}$ (for ${ }^{222} \mathrm{Rn}$ ) } \\
\hline & Root & Stem & Leaf & Fruit & Seed \\
\hline Thymus vulgaris $\mathrm{L}$. & 6.17 & 3.36 & 1.83 & ---- & ---- \\
\hline Coriandrum sativum L. & 6.52 & 3.41 & 1.93 & ---- & 1.12 \\
\hline Citrus colocynthis (L.) Schrad & 6.41 & 3.55 & 2.12 & 1.21 & ---- \\
\hline Chenopodium ambrosioides L. & 6.51 & 3.42 & 2.23 & ---- & ---- \\
\hline Retama sphaerocarpa L. & 6.61 & 3.65 & 2.34 & ---- & ---- \\
\hline Petroselinum crispum Mill. & 6.61 & 3.31 & 2.00 & 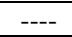 & 1.29 \\
\hline Ziziphus lotus (L.) Lam. & 6.33 & 3.55 & 1.96 & 1.40 & ---- \\
\hline Mentha spicata L. & 6.31 & 3.21 & 1.87 & ---- & ---- \\
\hline Artemisia herba-alba Asso. & 6.51 & 3.80 & 2.44 & ---- & ---- \\
\hline Rosmarinus officinalis L. & 6.62 & 3.65 & 2.51 & ---- & ---- \\
\hline Peganum harmala L. & 6.23 & 3.40 & 2.32 & ---- & 1.40 \\
\hline Marrubium vulgare L. & 6.63 & 3.57 & 2.07 & ---- & ---- \\
\hline Artemisia absinthium L. & 6.51 & 3.60 & 2.41 & ---- & ---- \\
\hline Mean TF & 6.45 & 3.50 & 2.15 & 1.30 & 1.28 \\
\hline
\end{tabular}

Table 5. TF values of thoron $\left({ }^{220} \mathrm{Rn}\right)$ to different parts of the studied medicinal plants

\begin{tabular}{|c|c|c|c|c|c|}
\hline \multirow[t]{2}{*}{ Medicinal plants } & \multicolumn{5}{|c|}{ Transfer Factor (TF) $\times 10^{-3}$ (for ${ }^{220} \mathrm{Rn}$ ) } \\
\hline & Root & Stem & Leaf & Fruit & Seed \\
\hline Thymus vulgaris L. & 4.52 & 2.46 & 1.26 & ---- & ---- \\
\hline Coriandrum sativum L. & 4.19 & 2.71 & 1.31 & ---- & 0.87 \\
\hline Citrus colocynthis (L.) Schrad & 4.36 & 2.86 & 1.34 & 1.06 & $\begin{array}{ll}---- \\
\end{array}$ \\
\hline Chenopodium ambrosioides L. & 4.25 & 2.68 & 1.26 & $\begin{array}{ll}--- \\
\end{array}$ & $\begin{array}{ll}--- \\
\end{array}$ \\
\hline Retama sphaerocarpa L. & 4.53 & 2.74 & 1.38 & $\begin{array}{ll}--- \\
\end{array}$ & $\begin{array}{ll}--- \\
\end{array}$ \\
\hline Petroselinum crispum Mill. & 4.69 & 2.85 & 1.27 & ---- & 1.02 \\
\hline Ziziphus lotus (L.) Lam. & 4.63 & 2.26 & 1.22 & 0.92 & ---- \\
\hline Mentha spicata L. & 4.76 & 1.98 & 1.37 & ---- & ---- \\
\hline Artemisia herba-alba Asso. & 4.71 & 2.24 & 1.37 & ---- & ---- \\
\hline Rosmarinus officinalis L. & 4.87 & 2.86 & 1.35 & $\begin{array}{ll}--- \\
\end{array}$ & $\begin{array}{ll}--- \\
\end{array}$ \\
\hline Peganum harmala L. & 4.57 & 2.71 & 1.27 & ---- & 1.04 \\
\hline Marrubium vulgare L. & 4.85 & 263 & 1.36 & ---- & $\begin{array}{ll}--- \\
\end{array}$ \\
\hline Artemisia absinthium L. & 4.77 & 2.36 & 1.34 & $\begin{array}{ll}--- \\
\end{array}$ & ---- \\
\hline Mean TF & 4.60 & 2.56 & 1.31 & 1.00 & 0.97 \\
\hline
\end{tabular}

Table 6. Effective dose rates $\left(\mathrm{D}_{\alpha}\right.$, in mSv. $\left.\mathrm{y}^{-1)}\right)$ due to radon and thoron inside various parts of the studied plants Medicinal plants

\begin{tabular}{|c|c|c|c|c|c|}
\hline \multirow[t]{2}{*}{ Medicinal plants } & \multicolumn{5}{|c|}{$\mathrm{D}_{\alpha}\left(\mathrm{mSv} \cdot \mathrm{y}^{-1}\right)$} \\
\hline & Root & Stem & Leaf & Fruit & Seed \\
\hline Thymus vulgaris $\mathrm{L}$. & 1.32 & 0.72 & 0.39 & ----- & ------ \\
\hline Coriandrum sativum L. & 1.12 & 0.92 & 0.33 & ----- & 0.19 \\
\hline Citrus colocynthis (L.) Schrad & 1.26 & 0.70 & 0.42 & 0.24 & ----- \\
\hline Chenopodium ambrosioides L. & 0.94 & 0.50 & 0.33 & ----- & ----- \\
\hline Retama sphaerocarpa L. & 1.17 & 0.65 & 0.41 & ----- & ----- \\
\hline Petroselinum crispum Mill. & 1.37 & 0.69 & 0.41 & ----- & 0.27 \\
\hline Ziziphus lotus (L.) Lam. & 1.16 & 0.65 & 0.36 & 0.25 & ----- \\
\hline Mentha spicata L. & 1.07 & 0.54 & 0.32 & ----- & ----- \\
\hline Artemisia herba-alba Asso. & 1.02 & 0.60 & 0.38 & ----- & ----- \\
\hline Rosmarinus officinalis L. & 1.23 & 0.68 & 0.46 & ----- & ----- \\
\hline Peganum harmala L. & 1.04 & 0.57 & 0.40 & ----- & 0.23 \\
\hline Marrubium vulgare L. & 1.33 & 0.74 & 0.52 & ------ & ------ \\
\hline Artemisia absinthium L. & 1.05 & 0.58 & 0.38 & ----- & ------ \\
\hline
\end{tabular}

\subsection{Dose Calculation}

Radon-222 and thoron-220 are important radionuclides for the assessment of radiation exposure to the public because of their wide distribution in the environment. Consequently, the annual radon effective dose rates $\left(D_{\alpha}\right)$ have been determined inside the different parts of the studied medicinal plant samples. Data obtained is shown in Table 6. We notice that these dose rates due to radon and thoron are lower inside the leaves and stems than those determined inside the roots of the studied plants. Annual effective dose rates values for radon and thoron $\left(D_{\alpha}\right)$ are found to vary from $0.19 \mathrm{mSv} \cdot \mathrm{y}^{-1}$ (inside the seed of Coriandrum sativum L.) to $1.37 \mathrm{mSv}^{-1} \mathrm{y}^{-1}$ (inside the root of Petroselinum crispum Mill.). Anomalous concentration values of radon and thoron and the annual effective dose 
rates are not found in these studied medicinal plant samples of this area. For the consumable parts of the studied plants, it can be seen that these doses are much below the annual dose limit of $1 \mathrm{mSv}$ for the general public.

The objective of this study was to contribute to understanding of the radon and thoron transfer from soil to different compartments (roots, stems and leaves) of these plants used in traditional medicine. The choice of this strategy is double; first, to analyze physical characteristics of radon and thoron transfer from soil-to-plant system; secondly, a concept of radiotoxicity evaluated by radon and thoron content of these medicinal plants will be analyzed in this case.

\section{Conclusions}

This study has shown that plants are able to extract solubilized radioelement from the subsurface environment. We can say that aqueous radioelement is readily extracted from the soil into vascular plant via the transpiration stream that radon is eventually released into the atmosphere via diffusion through the leaf cuticle.

The soil-to-plant transfer factor is an important parameter to estimate the concentrations of radionuclides and elements in plants using a transfer model. The transfer factor generally shows a very wide range of variation in the elements (roots, stems and leaves) of the studied medicinal plants. Therefore, it seems reasonable that the parameter used for the estimation of the transfer of the nuclides should be evaluated under site-specific conditions.

The soil-to-plant transfer factor (TF) is regarded as one of the most important parameters in environmental safety assessment needed for nuclear facilities (IAEA). This parameter is necessary for environmental transfer models, which are useful in the prediction of the radionuclide concentrations in agricultural crops for estimating dose impacts to human. In general, transfer factors show a large degree of variation dependent upon several factors such as soil type, species of plants, and other environmental conditions. These preliminary results have been used to design subsequent experiments in order to improve our knowledge of the radon and thoron in terrestrial and aquatic ecosystems.

Finally, the radiological study performed to quantify the transfer of radon and thoron in the studied medicinal plants has indicated that plant-specific effects seemed to be considerably important in mobilizing radionuclides in the soil for plant uptake.

\section{References}

[1] Etiope, G., Martinelli, G. 2002. Migration of carrier and trace gases in the geosphere: an overview. Physics of the Earth and Planetary Interiors 129: 185-204.

[2] Font, Li., Baixeras, C., Moreno, V., Bach, J. 2008. Soil radon levels across the Amer fault. Radiation Measurements 43: 319-323.

[3] UNSCEAR "United Nations Scientific Committee on the Effects of Atomic Radiation”, 1993. Sources and effects of ionizing radiation, United Nations Publication E 94, IX, 2-33.
[4] BEIR VI (Report on the committee on Biological Effects of Ionizing Radiation), 1999. Health effects of exposure to radon, National research council, National academy press. Washington DC.

[5] Oufni, L. 2003. Determination of the radon diffusion coefficient and radon exhalation rate in Moroccan quaternary samples using the SSNTD technique. Journal of Radioanalytical and Nuclear Chemistry 256: 581-586.

[6] Singh, S., Kumar, J., Singh, B., Singh, J. 1999. Radon diffusion studies in some building materials using SSNTDs. Radiation Measurements 30: 461-464.

[7] Gerzabek, M. H., Strebl, F., Temmel, B. 1998. Plant uptake of radionuclides in lysimeter experiments. Environmental Pollution 99: 93-103.

[8] Lee, K. H., Wang, H. K., Itokawa, H., Morris-Natschke, S. L. 2000. Current Perspectives on Chinese Medicines and Dietary Supplements in China, Japan, and the United States. Journal of Food and Drug Analysis 8: 219-228.

[9] Oufni, L., Misdaq, M. A., Boudad, L., Kabiri, L. 2001. Determination of alpha-dose rates and chronostratigraphical study of travertine samples. Journal of Radioanalytical and Nuclear Chemistry 247: 577-581.

[10] Singh, S., Kumar, A., Singh, B. 2002. Radon level in dwellings and its correlation with uranium and radium content in some areas of Himachal Pradesh, India. EnvironmentaI International 28: 97101.

[11] Barooah, D., Laskar, I., Goswami, A. K., Ramachandran, T.V. Nambi, K.S.V 2003. Estimation of indoor radon, thoron and their progeny using twin cup dosimeters with solid-state nuclear track detectors in Digboi of Upper Assam. Radiation Measurements 36: 461-463.

[12] Babai, K.S., Poongothai, S., Lakshmi, K.S., Punniyakotti, J., Meenakshisundaram, V. 2012. Estimation of indoor radon levels and absorbed dose rates in air for Chennai city, Tamilnadu, India. Journal of Radioanalytical and Nuclear Chemistry 293: 649-654.

[13] Radolic, V., Vukovic, B., Stanic, D., Katic, M. 2006. National survey of indoor radon levels in Croatia. Journal of Radioanalytical and Nuclear Chemistry 239: 87-90.

[14] Oufni, L., Taj, S., Manaut, B., Eddouks, M. 2011. Transfer of uranium and thorium from soil to different parts of medicinal plants using SSNTD. Journal of Radioanalytical and Nuclear Chemistry 287: 403-410.

[15] Misdaq, M.A., Aitnouh, F., Khajmi, H., Berrazzouk, S. 2001. A new method for evaluating radon and thoron -activities per unit volume inside and outside various natural material samples by calculating SSNTD detection efficiencies for the emitted -particles and measuring the resulting track densities. Appl. Radiat. Isot 55: 205-213.

[16] Biersack, J. P \& Ziegler, J. F. 1998. IBM Research, TRIM, Version 98.

[17] Herb, S. 2007. Measurement of radioactivity of ${ }^{238} \mathrm{U},{ }^{226} \mathrm{Ra},{ }^{210} \mathrm{~Pb}$, ${ }^{228} \mathrm{Th},{ }^{232} \mathrm{Th},{ }^{228} \mathrm{Ra},{ }^{137} \mathrm{Cs}$, and ${ }^{40} \mathrm{~K}$ in tea using gamma-spectrometry. Journal of Radioanalytical and Nuclear Chemistry 274: 63-66.

[18] Mollah, A.S., Aleya, B. 2001. A study on Transfer factors of ${ }^{60} \mathrm{Co}$, and ${ }^{65} \mathrm{Zn}$ from Soil to Plants in the Tropical Environment of Bangladesh. Environmental Monitoring and Assessment 68: 91-97.

[19] IAEA “International Atomic Energy Agency”. 1994. Handbook of Parameter Values for the Prediction of Radionuclide Transfer in Temperate Environments. A Guide Book Technical Report Series No.364, Vienna.

[20] ICRP International Commission on Radiological Protection. 1994. Dose Co-efficient for the Intakes of Radionuclides by Workers (ICRP Pub. No. 68). Pergamon Press, Oxford.

[21] ICRP "International Commission on Radiological Protection". 1996. Age-Dependent Doses to Members of the Public from Intake of Radionuclides: Part 5. Compilation of Ingestion and Inhalation Dose Co-efficient (ICRP Pub. No.72). Pergamon Press, Oxford.

[22] Eisenbud, M. 1973. Environmental radioactivity ( $2^{\text {nd }}$ ed.)," New York: Academic Press.

[23] Kathreen, R. 1984. Radioactivity in the environment: Sources, distribution and surveillance. Chur: Harwood Academic Publishers. 